\title{
State regulation of the land reclamation development at the regional level exemplified by Samara region
}

\author{
Ekaterina $V$. Lebedeva* and Ekaterina $V$. Bulankina \\ Samara State Agrarian University, Kinel 446442, Russia
}

\begin{abstract}
The article considers the role of land reclamation in the development of modern Russian agriculture, defines its role in the development of the domestic land reclamation industry of state regulation. The implementation of the state policy for the maintenance and development of the reclamation industry in the Samara region from 2015 to the present is analyzed. The preliminary results of its implementation are summarized. The material, technical and regulatory framework for the further development of land reclamation in the region is determined.
\end{abstract}

\section{Introduction}

Under the conditions of climate change, which in recent years has been manifested by frequent droughts or floods, land reclamation is considered as the best way to ensure the sustainability of agricultural production. Currently, irrigated lands account for $40 \%$ of world food production, including $60 \%$ of grain production. For Russia, where $80 \%$ of arable land is subject to arid phenomena, and about $20 \%$ to excessive moisture, the value of land reclamation is difficult to overestimate [1].

In modern conditions of the agroindustrial complex development and the state food safety policy implementation, the reliability of land reclamation and its effectiveness largely depend on an adequate management system. This circumstance, which requires decisionmaking in conditions of uncertainty and is associated with significant risk, significantly complicates reclamation system management in comparison with other objects and enterprises. Therefore, the scientifically reasoned operation of reclamation systems and its competent management based on long-term and shortterm forecasting are extremely important for the reclamation industry.

With regards to the strategic management of socio-economic processes, the state plays a leading role in shaping the optimal development mode for the modern land reclamation system, which is of great importance for the growth of agricultural production and the formation of food security.

The problem of state regulation of the land reclamation complex development in Russia has recently been increasingly reflected in the scientific literature. Experts in the field of land reclamation study the current state and prospects of the land reclamation industry development in the country and individual regions [1-4]. Specialists in the field of public administration of the agro-industrial complex analyze the problems of management and strategic development of the industry [5-7].

However, the problems of determining the prospects (technical and administrative) for the development of the domestic land reclamation complex, the distribution of powers between management levels and forms of ownership, allocation of budgetary funds and the use of extrabudgetary funds remain relevant. These issues are especially relevant at the level of constituent entities of the Russian Federation, i.e. at the regional governmental level. The implementation of regional policies in the field of land reclamation is important for

\footnotetext{
Corresponding author: chuko-chin-chino@mail.ru
} 
the development of an agro-industrial complex of individual constituent entities of the Russian Federation and large agglomerations of the country [8].

\section{Materials and methods}

According to UN estimates, by the middle of the 21st century humanity will face the global problem of food shortages. Therefore, even now it is necessary to pay attention to the prospect of the significant increase in agricultural production.

Meanwhile, the Russian agricultural sector is subject to the negative consequences of various kinds of instability factors. Risks of agricultural enterprises are the most complex and poorly predicted [6]. Agriculture being dependent on natural factors and having a pronounced seasonal, cyclical pattern of production, is a technically more backward industry than other sectors of the economy [5].

Developmental features of the agricultural sector of the economy make its state regulation inevitable, which is aimed both at supporting agricultural producers under the conditions of intense competition and overcoming periodic agrarian crises [9]. The current mechanism of state regulation of the agro-industrial complex is currently a program-targeted approach, an important condition for the development of which is the provision of targeted state programs with financial resources [7].

The basis for the development of the agro-industrial complex of the Russian Federation is the Doctrine of Food Security of the Russian Federation, which pays special attention to agroecological risks caused by adverse climatic changes.

To ensure food security and improve the competitiveness of Russian agricultural products in Russia, the State Program for the Development of Agriculture and Regulation of Agricultural Products, Raw Materials and Food Markets, which was designed until 2025, is implemented in its structure. It includes several basic areas, among which there is a subprogram "Development of Land Reclamation agricultural purposes of Russia". Within the framework of the direction of the State program "Ensuring the conditions for the development of the agro-industrial complex", the departmental program "Development of the reclamation complex of Russia" is being implemented.

The close attention to the development of the reclamation complex in the structure of ensuring the conditions for the development of the agro-industrial complex of the Russian Federation is determined by the special importance of land reclamation in sustainable food production, on the one hand, and the current state of the industry, on the other hand.

In Russia, the proportion of reclaimed land in the total agricultural land did not exceed $10 \%$ even in the context of an increase in land reclamation. Currently, the area of reclaimed land is only $7.9 \%$ of the arable land [3]. The area of reclaimed land in the Russian Federation, with its low productivity, currently cannot affect the neutralization of the risk of adverse weather conditions and the provision of food for the population of our country [2]. Moreover, according to the calculations of domestic scientists in the field of land reclamation, in our country it is necessary to have at least 10 million hectares of irrigated lands and at least 8 million hectares of drained land by 2025-2030 [1].

At the turn of the century, the Russian land reclamation industry fell into decay: significant areas of irrigated and drained lands were lost, part of the reclaimed lands degraded, and the territory of eroded and deserted lands grew. Reclamation systems, separately located hydraulic structures, special irrigation machines have become old and destroyed. In general, more than 30 million hectares of arable land have been removed from agricultural circulation in the territory of the Russian Federation. Currently, most of the reclaimed land (over 3.5 million hectares) is in poor condition. Over half of domestic irrigation systems (about 2.5 million hectares) need reconstruction and technical re-equipment.

Haing objectively assessed the current situation in the agricultural land reclamation industry, as well as natural risks, the Russian state has expanded the directions scope of the state support for the reclamation industry. The organizational mechanism for the development of the domestic reclamation industry was the programtarget method, which was expressed in the form of the federal target program "Development of Land Reclamation of Agricultural Land for 2014-2020".

State policy on the development of the reclamation industry is actively implemented in the Samara region. The strategic document that defines the prospects for the development of the land reclamation complex in the region is the Development Strategy for the agroindustrial complex of the Samara Region for the period until 2020, which also spells out the main targets for the development of land reclamation in the region starting 
from 2013, the state program "Development of Agriculture and Regulation of Agricultural Products, Raw Materials and Food Markets of the Samara Region" for 2014-2021, which included the subprogram "Development of Land Reclamation of Agricultural Land in the Samara Region for the period until 2020".

To implement the program at the expense of the federal and regional budgets, agricultural producers operating in the Samara region were provided with subsidies for reimbursing the expenses associated with the production of agricultural products in terms of costs for the construction and reconstruction of reclamation systems.

The level of state program activities funding has always remained high. Specifically, in 2015 they were $85.3 \%$ (109.8 million rubles were planned; 93.7 million rubles were disbursed), in $2016-100 \%$, taking into account the stipulated funds (76.280 million rubles were planned; 76.280 million rubles were spent), in 2017 $100 \%$ taking into account the funds provided (75.770 million rubles were provided; 75.770 million rubles were spent).

In 2015-2017 agricultural producers of the Samara region gained effective state support in the form of partial reimbursement of the costs of construction and reconstruction of reclamation systems. Thus, they confidently invested their own financial resources in projects for the creation and reconstruction of irrigated areas using the latest reclamation equipment.

Due to the fact that the federal target program "Development of land reclamation of agricultural lands of Russia for 2014-2020" was included in the State program for the development of agriculture and regulation of agricultural products, raw materials and food markets for 2013-2020, the implementation of an independent development program land reclamation of agricultural lands of the Samara region was completed in 2017, and the direction itself was included in the state program of Samara region field "Development of agriculture and regulation of markets for agricultural products, raw materials and food of the Samara region" for 2014-2020 in the form of subprogram.

The total amount of funding for the activities of the Subprogram at the expense of the regional budget in 2018-2020 was determined at 373.93 million rubles; the amount of funds of the regional budget amounted to 172.80 million rubles; the amount of funds of the regional budget formed at the expense of federal budget funds received in accordance with the current legislation in the regional budget 201.13 million rubles; extrabudgetary sources in the amount of $1,634.33$ million rubles were also attracted to implement the program.

As a result of solving the tasks posed to the subprogram "Development of Land Reclamation of Agricultural Land in the Samara Region for the Period until 2021", it is planned to increase the gross agricultural output in farms of all categories (in comparable prices) in 2021 (to the level of 2013) by $13.6 \%$, food production, including drinks (in comparable prices) by $17.8 \%$, gross crop production (in comparable prices) by $12.1 \%$, production of grain and leguminous crops by $59.3 \%$, gross output livestock production (in comparable prices) by $37.2 \%$, livestock and poultry for slaughter in households of all categories (in live weight) by $10.5 \%$, milk in households of all categories by $7.8 \%$.

We used both the mentioned strategic documents and the reporting documentation of the Samara Region Ministry of Agriculture and Food as well as official information on the development of the agro-industrial complex in the region to analyze the implementation of the state policy for the development of the Samara region reclamation complex.

\section{Results}

The Samara region is located in the southeastern part of the European territory of Russia in the continental climate zone of temperate latitudes. The waters of the region are represented by surface and underground sources, which include rivers and lakes, artificial reservoirs. The main river of the region is the Volga.

Agriculture plays a special role in the economy of the Samara region. More than 500 large agricultural enterprises, 1951 peasant (farm) enterprises, over 290 thousand personal subsidiary farms of the population and about 1000 enterprises of the food, processing industry and agrotechnical service represent the agricultural sector of the region. The main area of specialization is the production of grain, sunflower, potatoes and vegetables, milk and meat.

In the Samara region there are more than 4 million hectares of agricultural land. The area of farmland in the composition of agricultural land is 3.8 million hectares, including 2.8 million hectares of arable land, 800 thousand hectares of natural forage land.

The gross agricultural output of the region in 2018 amounted to 85.4 billion rubles. In the structure of gross agricultural output, the crop production was $64.5 \%$, livestock production was $35.5 \%$. The proportion of agricultural products in the Samara region in all-Russian production is $1.7 \%$.

On the irrigated lands of the Samara region 125 thousand tons of potatoes (98\% of the total volume produced in agricultural enterprises and peasant farms of the region), 94 thousand tons of vegetables $(86 \%), 8$ thousand tons of grain $(0.3 \%), 15$ thousand tons of soybeans (55 $\%)$, more than 3 thousand tons of fruit and 
berry crops (24\%) are produced. The average yield on irrigated lands for potatoes and vegetables is 340 centners per hectare (up to 1000 centners per hectare on individual farm fields), grain crops up to 100 centners per hectare, fruit crops up to 150 centners per hectare, and soybeans up to 30 centners per hectare.

The potential for the development of agricultural irrigation in the municipal areas of the Samara region is shown in Table 1.

The measures implemented by the Ministry of Agriculture and Food of the Samara Region in the field of land reclamation for agricultural land through the implementation of the program "Development of land reclamation of agricultural land in the Samara region for the period until 2020" provided positive dynamics for the main indicators of the development of irrigation systems in the region.

In 2015, 3.162 thousand hectares of irrigated land were commissioned through reconstruction, technical re-equipment and construction of new reclamation systems. Specifically, 1.56 thousand hectares in 2016 and 1.78 thousand hectares in 2017 were put into service. Accordingly, the volume of crop production on irrigated agricultural lands increased as follows: in 2015 it amounted to $56.8 \%$, in 2016 to 44 $\%$, and in 2017 to $28 \%$. By 2018, the area of irrigated land used in agricultural production of the Samara region amounted to 134.7 thousand hectares. State irrigation systems are located on 82.7 thousand hectares of this land (this area of irrigated land occupies $5 \%$ of the total arable land).

Table 1. Gross harvest from irrigated lands, taking into account the realization of the region potential, thousand tons

\begin{tabular}{|c|c|c|c|c|c|}
\hline Indicator/year & 2019 & 2021 & 2023 & 2024 & $\begin{array}{c}\text { The growth of } \\
\text { 2024 by 2018, } \\
+/-\end{array}$ \\
\hline $\begin{array}{c}\text { Cereals and } \\
\text { leguminous } \\
\text { crops (export- } \\
\text { oriented) }\end{array}$ & 14.3 & 26.7 & 39.1 & 45.3 & 37.2 \\
\hline $\begin{array}{c}\text { Oilseeds } \\
\text { (export- } \\
\text { oriented) }\end{array}$ & 22.2 & 34.6 & 47.0 & 58.3 & 43.3 \\
\hline Vegetables & 93.2 & 105.6 & 118.0 & 106.3 & 20.3 \\
\hline
\end{tabular}

\begin{tabular}{|c|c|c|c|c|c|}
\hline Potatoes & 125.1 & 125.1 & 125.1 & 128.0 & 2.9 \\
\hline $\begin{array}{c}\text { Fruit and } \\
\text { berry } \\
\text { plantations }\end{array}$ & 10.4 & 22.8 & 35.2 & 12.2 & 9.0 \\
\hline
\end{tabular}

The largest part of this fund is located along eighteen state irrigation systems, which include 502 hydraulic structures, 600 kilometers of canal network and 71 pumping stations, which are on the balance sheet of the federal state institution FSBI "Samarameliovodkhoz Management" subordinate to the Ministry of Agriculture of the Russian Federation.

Herewith, most of the irrigation systems are not used at full capacity bcause 125.6 thousand ha are in need of reconstruction. In 2019, 111.2 thousand hectares (83\%) were not watered due to a malfunction in the irrigation network and the lack of irrigation equipment. More than $75 \%$ of sprinkler machines and installations are operated outside the standard service life. In the next 5 years, a complete replacement and modernization of the existing irrigation equipment park in the region will be required.

Despite the work aimed to develop the region reclamation complex, the irrigation system of the Samara region is currently not able to have a decisive influence on neutralizing the risk of adverse weather conditions, which in the future can negatively affect the pace of socioeconomic development of the region.

Due to the fact that the main arrays of irrigation systems were built in the 60-90s of the last century, 76.5 thousand hectares are currently in need of reconstruction and full restoration. According to expert estimates, restoration of the entire irrigated fund of the region requires up to 20 billion rubles (the cost of restoring 1 hectare of irrigated land is 175-280 thousand rubles with irrigation technology implemented by wide-angle machines and 150 thousand rubles per 1 hectare with drip irrigation).

Most of the irrigated agricultural land in the Samara region, where the restoration of irrigation is economically feasible being 36.6 thousand hectares is owned by the general share and private property, 2.8 thousand hectares are in the regional property, 5.9 thousand hectares are in the ownership of municipal districts, 2.6 thousand ha are in federal ownership (Table 2). 
Table 2. Ownership structure of the Samara region irrigated lands in need of restoration and reconstruction, hectares

\begin{tabular}{|c|c|c|c|c|}
\hline Municipal area & $\begin{array}{c}\text { Common } \\
\text { land and } \\
\text { private land }\end{array}$ & $\begin{array}{c}\text { Municipal } \\
\text { land }\end{array}$ & $\begin{array}{c}\text { Lands of } \\
\text { the Samara } \\
\text { region }\end{array}$ & $\begin{array}{c}\text { Lands of } \\
\text { federal } \\
\text { property }\end{array}$ \\
\hline Privolzhsky & 14.6 & 4.7 & - & - \\
\hline Stavropolsky & 8.4 & - & - & - \\
\hline Bezenchuksky & 5.3 & 1.2 & 2.8 & 2.6 \\
\hline Volzhsky & 2.8 & - & - & - \\
\hline Hvorostyansky & 2.3 & - & - & - \\
\hline Krasnoarmeysky & 1.0 & - & - & - \\
\hline Sergievsky & 1.0 & - & - & - \\
\hline Neftegorsky & 1.2 & - & - & - \\
\hline Syzransky & 2.0 & - & - & - \\
\hline Kinelsky & 2.5 & - & - & - \\
\hline TOTALLY: & 36.6 & 5.9 & 2.8 & 2.6 \\
\hline
\end{tabular}

One of the constraining factors in the development and restoration of irrigation in the region is the inefficient use of irrigated land by owners and tenants. A significant part of the irrigated land fund is not used to full capacity by the owners. Out of 82 land users whose lands are located along the state irrigation systems in the region, only 26 or $31 \%$ of their total number use irrigation. On the remaining lands, such crops as sunflower, barley, cultivating with the use of irrigation is not economically feasible.

Currently, commercially viable export-oriented crops on irrigation will allow land users to be interested in obtaining higher profits. Yield and economic efficiency of irrigation on the lands of the Samara region for agricultural use, address Table 3 .

Special attention is required to the conditions of state irrigation systems, the total depreciation of structures, machinery and equipment which reaches $71 \%$, and the filling of the channel network being 30-50 \%. Meanwhile, these are the irrigation systems that should be considered as the basis for the restoration and development of the regional reclamation system.

The state irrigation system Kondurchinskaya was created over 30 years ago. Its basis is the Kondurchinsky reservoir (water volume is $25.3-31.5$ million $\mathrm{m}^{3}$ ), which is currently in a satisfactory condition and can serve as a reference point for the restoration of irrigation systems in the northern regions of the Samara region on an area of more than 1000 hectares. Similar reservoirs are located in the municipal areas of Volzhsky (Chernovskoye), Bogatovsky, Borsky (Kutulukskoye), Bolsheglushitsky (Talovskoye). In the municipal district of Stavropolsky, 8.5 thousand hectares of farmland located near state irrigation systems (Zhigulevskaya and Tolyattinsky) are used as rainfed ones and can potentially be restored.

In the municipal district of Bezenchuksky, 5.3 thousand hectares of farmland located near state irrigation systems are used as rainfed ones and can also be restored. In addition, restoration of irrigation on an area of 2.6 thousand hectares is economically feasible on the lands of the Russian Federation, which are under the operational management of the Federal State Budgetary Institution "Krasnogorskoye".
Table 3. Harvest and cost-effectiveness of irrigation

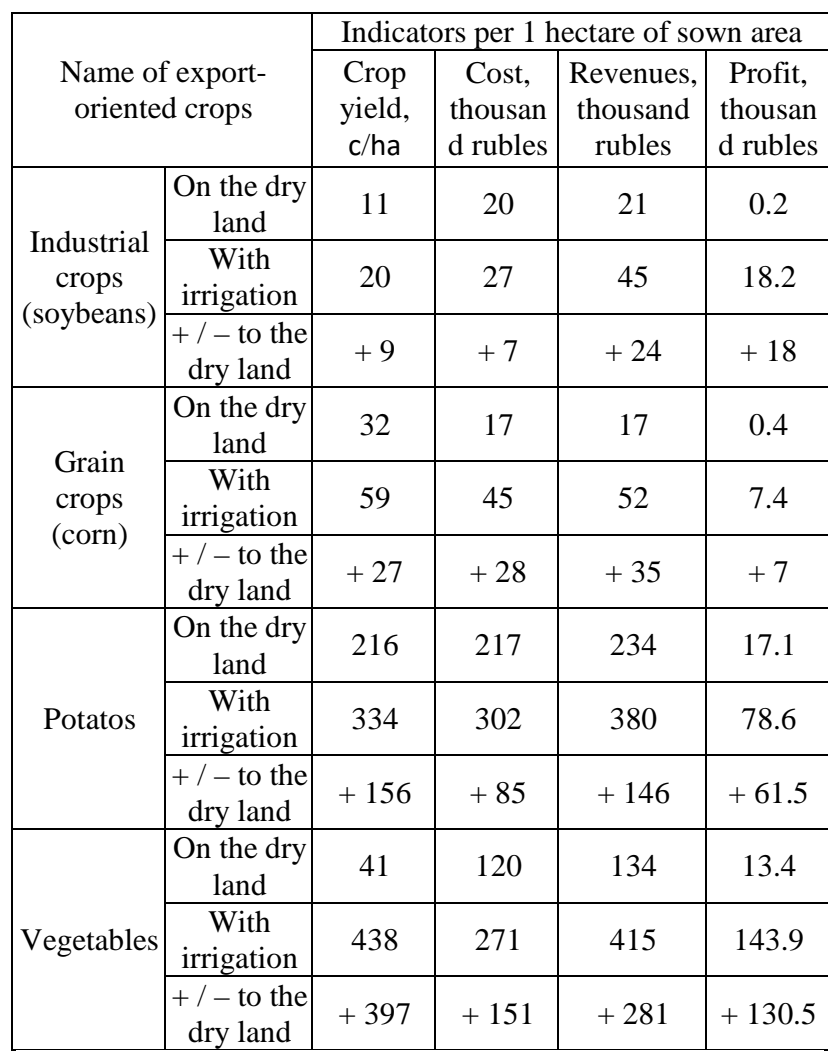

The potential for restoration of irrigation on the lands of the Samara region, which are under the operational management of the State Unitary Enterprise Kupinsky, is 2.8 thousand hectares. Potentially irrigated lands with an area of 1.5 thousand hectares located along the borders of the Kutuluk reservoir of the Borsky district of the Samara region are being processed by the state-owned enterprise Agricultural Holding OOO "Pokrovskoye". In the municipal district Hvorostyansky, 2.3 thousand hectares of farmland located near state irrigation systems are used as rainfed ones and can also be restored. A large area of potentially irrigated land is occupied by agricultural producers operating in areas 1 and 2 of the Spassky irrigation system.

Accounting and use of the features and reserves of the Samara Region irrigation system will help both in tactical and strategic management of the regional reclamation complex development.

\section{Conclusion}

For the planned development of state support for the region reclamation complex, a regional strategy for its development is necessary. An increase in reclaimed land to 47 thousand hectares should be considered as the target of the Development Strategy of the region reclamation complex. At the same time, on irrigated lands, it is necessary to carry out technical re-equipment of existing reclamation systems on an area of 6 
thousand hectares, reconstruction on an area of 8 thousand hectares and new construction on an area of 11 thousand hectares.

The development strategy of the Samara Oblast reclamation complex should be aimed to achieve such goals as restoration and development of the reclamation fund, increasing soil fertility to an optimal level, developing priority areas of agricultural production on reclaimed land, developing fodder production on reclaimed land in accordance with the growth rate of cattle, environmentally regulated use of agricultural, land, water and other renewable natural resources and general conditions of agricultural operation on the reclaimed land for the most complete and rational use of natural resources potential, agrolandscapes neutralizing effect of drought and hot winds on crop productivity while maintaining, restoring soil fertility and reproduction and water conservation.

Additionally, the development of the Strategy as a separate document is determined by the need to create a convenient tool for business that gives an idea of the economic and industry priorities for the reclamation complex development as well as the tools used to support investment activities in the long term.

\section{References}

1. V.V. Melixov, Irrigated Agriculture, 4 (2017)

2. I. P. Kruzhilin, Bull. of the Russ. Acad. of Agricult. Sci., 1 (2011)

3. N.N. Dubenok, Bull. of the Timiryazev Agricult. Acad., 1 (2014)

4. E.Yu. Kalinicheva, N.V. Pol'shakova, A.S. Kolomejchenko, Herald of Agrar. Sci., 3 (2017)

5. S.D. Vlasov, Bull. of the Saratov State Socio-Econ. Univer., 5 (2012)

6. O.A. Golikova, I.V. Joda, Socio-Econ. Phenomena and Proc., 9 (2014)

7. A.A. Mokrushin, Bull. of the Adygeya Univer., The Econ. Ser., 3 (2017)

8. E.V. Bulankina, S.V. Grankina, E.V. Lebedeva, Samara-Tolyatti agglomeration as a mechanism for the development of a regional economy (2017)

9. A.K. Ibragimov, O.V. Mixajlova, T.T. Duplina, Bull. of the Kursk State Agricult. Acad., 2 (2013) 